\title{
THE CLINICAL PROFILE OF CHILDHOOD OPTIC NEURITIS
}

\author{
Marco Aurélio Lana-Peixoto', Gustavo Cardoso de Andrade ${ }^{2}$ \\ For the Brazilian Committee for Treatment and Research in Multiple Sclerosis (BCTRIMS)
}

\begin{abstract}
Purpose: To report the clinical features and outcome of a series of children with optic neuritis. Methods: We reviewed the medical records of patients up to 16 years old with optic neuritis. Group 1 comprised children seen up to two weeks after the onset of visual loss; Group 2 comprised patients already harboring optic atrophy. Results: There were 15 boys and 12 girls. The mean age was 10.9 years. Bilateral optic neuritis occurred in 10. Optic disc pallor was found in 35\%, edema in 46\%, and $19 \%$ had normal fundus. During follow-up visual acuity improved in all but one eye in Group 1, and in six of seven eyes in children in Group 2. Just one child converted to multiple sclerosis. Conclusions: This study shows that the clinical features of childhood optic neuritis differ from those observed in adults. In children it has a better visual outcome and a lower conversion rate to multiple sclerosis than in adults.
\end{abstract}

KEY WORDS: childhood optic neuritis, visual outcome, multiple sclerosis.

\begin{abstract}
0 quadro clínico da neurite óptica na infância
RESUMO - Objetivos: Descrever as características clínicas e evolutivas da neurite óptica na infância. Métodos: Foram revistos os prontuários de crianças até 16 anos de idade neurite óptica. Os pacientes foram divididos em dois grupos. Grupo 1 referia a crinças examinadas até duas semanas após o início da perda visual; Grupo 2 foi formado por crianças já apresentando atrofia óptica ao primeiro exame. Resultados: Foram encontrados 15 meninos e 12 meninas, com idade média de 10,9 anos. Neurite óptica bilateral foi observada em 10 crianças. 0 disco óptico estava pálido em $35 \%$ dos casos, edemaciado em $46 \%$ e normal em $19 \%$. Exame durante follow-up demonstrou melhora da acuidade visual em todos, exceto em um caso no Grupo 1 e em 6 de 7 olhos no Grupo 2. Apenas uma criança desenvolveu esclerose múltipla. Conclusões: Este estudo demonstrou que as características clínicas da neurite óptica na infância diferem das observadas em adultos. Em crianças, a recuperação visual é melhor, e a taxa de conversão para a esclerose múltipla é mais baixa.
\end{abstract}

PALAVRAS-CHAVE: neurite óptica na infância, recuperação visual, esclerose múltipla.

Childhood optic neuritis is a rare condition that differs from adult-onset optic neuritis in some clinical and evolutive aspects. It is widely accepted that in children, attacks of optic neuritis usually occur following a febrile illness, tend to affect both eyes, are frequently associated with swollen discs, improve rapidly, and have a low conversion rate to multiple sclerosis (MS) ${ }^{1-7}$. On the other hand, optic neuritis in adults is usually unilateral, predominantly affects the retrobulbar portion of the optic nerve, and presents a high conversion rate to $\mathrm{MS}^{8,9}$.

Although these facts have been accepted on a worldwide basis few series of children with optic neuritis have been studied. In addition to that it is well known that genetic and environmental factors play an important role in the prevalence and clinical expression of demyelinating diseases. Our previous studies have demonstrated that in Brazil MS has some clinical features different from those most commonly seen in other Western countries ${ }^{10,11}$. Furthermore, isolated demyelinating optic neuritis in Brazil converts to MS in a much lower rate as compared to those reported in North America and Europe ${ }^{11}$. It is, therefore possible that in our country idiopathic optic neuritis in children may harbor different characteristics from those reported in other geographical areas or population groups.

In order to clarify some of these issues we looked at our series of childhood optic neuritis and herein we report our observations.

\footnotetext{
${ }^{1}$ Associate Professor, Department of Neuro-Ophthalmology, Hospital São Geraldo, Federal University of Minas Gerais Medical School, Belo Horizonte MG, Brazil. ${ }^{2}$ Fellow, Department of Neuro-Ophthalmology, Hospital São Geraldo, Federal University of Minas Gerais Medical School, Belo Horizonte, Brazil.

Received 13 December 2000, received in final form 9 March 2001. Accepted 20 March 2001. 


\section{METHOD}

The medical records of all patients with ages up to 16 years and the diagnosis of optic neuritis who were examined by one of us in a 16-year period were reviewed. The inclusion criteria for the diagnosis of idiopathic optic neuritis were: (1) history of acute loss of central vision; (2) no evidence of neurologic, metabolic, toxic, vascular, hereditary, or compressive etiology; (3) no evidence of retinal exudates or other retinal lesions; (4) at least two of the following: a relative afferent pupillary defect, a color vision deficit, a nerve fiber bundle defect on field examination, and a swollen or pale optic disc. Cases of neuromyelitis optica or MS in which optic neuritis was not the initial symptom were also discarded.

The selected cases fulfilling the above criteria for the diagnosis of optic neuritis were then divided into two groups according to the interval between the onset of the visual loss and the neuro-ophthalmic examination at our Department. Group 1 comprised children seen up to two weeks after the onset of visual loss; Group 2 comprised patients first examined by us two weeks or later following visual loss and already harboring optic disc pallor.

Patients were further classified as having unilateral or bilateral optic neuritis. Bilateral simultaneous optic neuritis was defined as involvement of both eyes either at the same time or within a period of two weeks, after which it was considered as sequential bilateral optic neuritis. Conversion to MS was defined as the occurrence of other signs of central nervous deficit according to Poser's Committee criteria ${ }^{12}$.

The charts were then analyzed in relation to children's age at onset of the visual loss, sex, history of a prodrome, occurrence of eye pain, laterality, best corrected visual acuity (VA) at the first examination, color vision assessed by Ishihara's pseudoisochromatic plates, fundoscopic examination and visual field examination by Goldmann's or automated perimetry.

Long-term follow-up noted recurrence of visual loss, final visual acuity, color plates, ophthalmoscopic appearance of the optic nerves, interval medical history and neurological examination to detect any symptom or sign of central nervous system involvement which could herald the development of MS. Cerebrospinal fluid (CSF) examination, whenever available was analyzed in relation to number and types of cells, glucose and protein concentration, and protein electrophoresis. As the presence of oligoclonal bands in the CSF was not searched by isoelectric focusing electrophoresis it was not considered in the present study. Most patients did not have a brain MRI as this test was not available to them at the time of onset of the optic neuritis. When it was performed the presence of T2-weighted hyperintense areas in the optic nerves or brain white matter was noted.

\section{RESULTS}

Twenty-seven patients (Table 1) fulfilled the set of criteria as described above for the diagnosis of childhood optic neuritis. There were 15 boys and 12 girls with ages ranging from 3 to 16 years (mean 10.9 years). Three patients were under six; eight were between six and 10, and 16 were 11 to 16 .

There were 37 involved eyes as 10 children (37\%) had bilateral optic neuritis (eight bilateral simultaneous, and two bilateral sequential) and 17 (63\%) had unilateral attacks ( 8 in the right eye and 9 in the left eye). Recurrent optic neuritis occurred in one child.

In 10 patients (37\%) an infection had occurred within two weeks before the onset of optic neuritis. In nine of these patients there was a febrile condition secondary to an upper respiratory infection, whereas in one patient the onset of optic neuritis was associated with immunization as part of treatment for recurring furunculosis due to Staphylococcus aureus.

A positive history of eye pain could be collected from the medical records of 10 children (37\%), preceding by a few days or in association with the onset of visual loss.

Neuro-ophthalmic examination was performed within a two-week period following the onset of the visual loss in 19 patients, whereas in the remaining eight children it was done after an interval up to nine years after visual failure had been noticed. There were 24 affected eyes in Group 1 and 13 in Group 2. In Group 1 VA was normal in one eye; $20 / 50$ or better in six (25\%); $20 / 60$ to $20 / 200$ in seven (29\%); and $20 / 400$ or worse in 11 eyes (46\%). In Group 2 VA was $20 / 50$ or better in two eyes (15\%); $20 / 60$ to $20 / 200$ in seven (54\%); and $20 / 400$ or worse in four (31\%).

All children with ages or VA suitable for color vision assessment showed some degree of color discrimination deficit. Fundoscopic examination disclosed optic disc edema in 17 eyes (46\%) and pallor in 13 (35\%). One child had a pseudo Foster-Kennedy syndrome. In six patients - seven eyes (19\%) - the fundus appearance was normal suggesting retrobulbar optic neuritis. Two of these patients had bilateral simultaneous optic neuritis; one with a bilateral simultaneous retrobulbar optic neuritis, and the other with optic disc edema in one eye and a retrobulbar involvement in the fellow eye.

Visual fields by perimetry were recorded in 20 affected eyes. In all of them a defect could be found (Table 2 ). In $50 \%$ of these eyes a central or cecocentral scotoma was detected.

A CSF analysis was performed in 12 children. In all of them cytology and the number of cells, as well as the protein concentration were within normal limits. 
Table 1. Children with optic neuritis.

\begin{tabular}{|c|c|c|c|c|c|c|c|c|}
\hline Case & $\begin{array}{l}\text { Age, } \\
\text { Sex }\end{array}$ & $\begin{array}{l}\text { Febrile } \\
\text { illness }\end{array}$ & $\begin{array}{l}\text { Eye } \\
\text { pain }\end{array}$ & Laterality & $\begin{array}{l}\text { Visual } \\
\text { acuity }\end{array}$ & $\begin{array}{l}\text { Optic } \\
\text { disc }\end{array}$ & $\begin{array}{l}\text { Color } \\
\text { deficit }\end{array}$ & Visual field \\
\hline 1 & $11 \mathrm{~F}$ & + & - & LE & $\mathrm{CF}$ & pallor & + & ND \\
\hline 2 & $12 \mathrm{M}$ & - & - & LE & $20 / 800$ & pallor & + & ND \\
\hline 3 & $6 \mathrm{~F}$ & - & - & $\begin{array}{l}\text { BS } \\
\text { RE } \\
\text { LE }\end{array}$ & $\begin{array}{l}20 / 400 \\
C F\end{array}$ & $\begin{array}{l}\text { edema } \\
\text { edema }\end{array}$ & $\begin{array}{l}+ \\
+\end{array}$ & $\begin{array}{l}\text { ND } \\
\text { ND }\end{array}$ \\
\hline 4 & $9 \mathrm{~F}$ & + & + & $\begin{array}{l}\text { BS } \\
\text { RE } \\
\text { LE }\end{array}$ & $\begin{array}{l}\text { NLP } \\
\text { NLP }\end{array}$ & $\begin{array}{l}\text { edema } \\
\text { edema }\end{array}$ & $\begin{array}{l}\text { ND } \\
\text { ND }\end{array}$ & $\begin{array}{l}\text { ND } \\
\text { ND }\end{array}$ \\
\hline 5 & $15 \mathrm{M}$ & - & - & LE & $20 / 50$ & edema & + & cecocentral scotoma \\
\hline 6 & $3 \mathrm{M}$ & + & - & $\begin{array}{l}\text { BS } \\
\text { RE } \\
\text { LE }\end{array}$ & $\begin{array}{l}20 / 60 \\
20 / 100\end{array}$ & $\begin{array}{l}\text { pallor } \\
\text { pallor }\end{array}$ & $\begin{array}{l}\text { ND } \\
\text { ND }\end{array}$ & $\begin{array}{l}\text { ND } \\
\text { ND }\end{array}$ \\
\hline 7 & $11 \mathrm{~F}$ & - & - & LE & $20 / 200$ & normal & + & central scotoma \\
\hline 8 & $12 \mathrm{M}$ & + & + & $\mathrm{RE}$ & $20 / 50$ & pallor & + & superior altitudinal defect \\
\hline 9 & $16 \mathrm{~F}$ & - & - & $\begin{array}{l}B S \\
R E \\
L E\end{array}$ & $\begin{array}{l}20 / 40 \\
20 / 30\end{array}$ & $\begin{array}{l}\text { normal } \\
\text { normal }\end{array}$ & $\begin{array}{l}+ \\
+\end{array}$ & $\begin{array}{l}\text { nasal defect } \\
\text { inferior arcuate defect }\end{array}$ \\
\hline 10 & $16 \mathrm{M}$ & - & - & LE & HM & edema & ND & ND \\
\hline 11 & $16 \mathrm{M}$ & - & + & $\mathrm{RE}$ & $\mathrm{CF}$ & normal & + & central scotoma \\
\hline 12 & $13 \mathrm{M}$ & - & - & LE & $20 / 200$ & edema & + & inferior arcuate defect \\
\hline 13 & $12 \mathrm{~F}$ & - & - & $\begin{array}{l}B S \\
R E \\
L E\end{array}$ & $\begin{array}{l}20 / 200 \\
20 / 200\end{array}$ & $\begin{array}{l}\text { edema } \\
\text { edema }\end{array}$ & $\begin{array}{l}+ \\
+\end{array}$ & $\begin{array}{l}\text { superior arcuate defect } \\
\text { central scotoma }\end{array}$ \\
\hline 14 & $5 \mathrm{M}$ & + & - & RE & $20 / 400$ & pallor & + & contraction \\
\hline 15 & $10 \mathrm{~F}$ & + & - & $\begin{array}{l}\text { BS } \\
\text { RE } \\
\text { LE }\end{array}$ & $\begin{array}{l}20 / 200 \\
20 / 200\end{array}$ & $\begin{array}{l}\text { pallor } \\
\text { pallor }\end{array}$ & + & $\begin{array}{l}\text { contraction } \\
\text { contraction }\end{array}$ \\
\hline 16 & $4 \mathrm{M}$ & - & + & $\begin{array}{l}\text { Bseq } \\
\text { RE } \\
\text { LE }\end{array}$ & $\begin{array}{l}20 / 30 \\
\text { CF }\end{array}$ & $\begin{array}{l}\text { pallor } \\
\text { edema }\end{array}$ & + & $\begin{array}{l}\text { ND } \\
\text { ND }\end{array}$ \\
\hline 17 & $13 \mathrm{M}$ & + & + & RE & $20 / 25$ & edema & + & central scotoma \\
\hline 18 & $9 \mathrm{~F}$ & + & + & $\mathrm{RE}$ & $\mathrm{CF}$ & edema & ND & contraction \\
\hline 19 & $14 \mathrm{M}$ & - & + & $\begin{array}{l}\text { Bseq } \\
\text { RE } \\
\text { LE }\end{array}$ & $\begin{array}{l}20 / 25 \\
20 / 100\end{array}$ & $\begin{array}{l}\text { normal } \\
\text { edema }\end{array}$ & + & $\begin{array}{l}\text { superior altitudinal defect } \\
\text { cecocentral scotoma }\end{array}$ \\
\hline 20 & $9 \mathrm{~F}$ & + & + & $\begin{array}{l}B S \\
R E \\
L E\end{array}$ & $\begin{array}{l}\mathrm{CF} \\
\mathrm{CF}\end{array}$ & $\begin{array}{l}\text { edema } \\
\text { edema }\end{array}$ & + & $\begin{array}{l}\text { ND } \\
\text { ND }\end{array}$ \\
\hline 21 & $13 \mathrm{M}$ & - & - & LE & $\mathrm{CF}$ & normal & + & ND \\
\hline 22 & $14 \mathrm{M}$ & - & + & LE & $20 / 200$ & pallor & + & cecocentral scotoma \\
\hline 23 & $6 \mathrm{M}$ & - & - & RE & $20 / 800$ & pallor & + & ND \\
\hline 24 & $10 \mathrm{~F}$ & + & - & $\begin{array}{l}\text { BS } \\
\text { RE } \\
\text { LE }\end{array}$ & $\begin{array}{l}20 / 200 \\
20 / 200\end{array}$ & $\begin{array}{l}\text { pallor } \\
\text { pallor }\end{array}$ & + & $\begin{array}{l}\text { cecocentral scotoma } \\
\text { cecocentral scotoma }\end{array}$ \\
\hline 25 & $10 \mathrm{~F}$ & - & - & RE & $20 / 20$ & edema & + & ND \\
\hline 26 & $16 \mathrm{M}$ & - & + & LE & $20 / 200$ & edema & + & central scotoma \\
\hline 27 & $16 \mathrm{M}$ & - & + & LE & $20 / 200$ & edema & + & central scotoma \\
\hline
\end{tabular}

BS, bilateral simultaneous; Bseq, bilateral sequential. 
Table 2. Visual field examination in childhood optic neuritis.

\begin{tabular}{lcc}
\hline Visual field defect & Number of eyes & Percentage \\
\hline Central scotoma & 5 & 25 \\
Cecocentral scotoma & 5 & 25 \\
Contraction & 4 & 20 \\
Arcuate defect & 3 & 15 \\
Altitudinal defect & 2 & 10 \\
Vertical defect & 1 & 5 \\
\hline
\end{tabular}

In five children protein electrophoresis disclosed increased content of $\gamma$-globulin.

Brain MRI was performed in six cases, showing normal results in three, and signs of sinusitis in one. In one child there was a T2-weighted hyperintense lesion in the involved optic nerve, whereas in another there were a few T2-weighted hyperintense lesions scattered in the brain white matter.

Seventeen children - 12 in Group 1 and five in Group 2 - could be evaluated in follow-up of variable extension. The follow-up period ranged from 1 to 41 months (median 13 months). Visual acuity improved in all but one eye in Group 1, and in six out of seven eyes in Group 2 examined at follow-up (Table 3). In Group $150 \%$ of patients recovered normal VA whereas $88 \%$ had VA $20 / 50$ or better during follow-up. The VA was $20 / 200$ or worse in $6 \%$ at follow-up as compared to $25 \%$ at the initial examination, and there was no patient with VA worse than $20 / 800$ at follow-up as compared to $42 \%$ at the onset. The only patient in this Group who did not get better had retrobulbar neuritis and VA of 20/200 and was followed for 30 months. Another patient with acute anterior optic neuritis and sinusitis had VA of $\mathrm{CF}$ (counting fingers) at the onset which turned out to 20/800 after six months. All other Group 1 patients got improvement greater than two lines at the Snellen chart. Four eyes in Group 1 patients got one line improvement in their visual acuity; two had two lines improvement and one eye had no VA change during follow-up. In Group 2 no change in the percentage of patients with VA 20/50 or better was observed, whereas $85 \%$ of patients examined at follow-up had VA between $20 / 60$ to $20 / 200$, as compared to $54 \%$ at first examination. No patient in this Group was found with VA worse than 20/200 at follow-up as compared to $29 \%$ with this VA found at the initial examination. Figures 1 and 2 show the VA at the initial evaluation and follow-up in Group 1 and Group 2 patients.
Just one child in this series converted to MS. He was a 16-year-old boy who developed ataxia and decreased sensation in the right upper limb 18 months after the onset of acute retrobulbar optic neuritis. CSF examination had been normal but MRI had shown an abnormal higher signal intensity area on the involved optic nerve. Repeated MRI then showed a number of abnormal T2-weighted hyperintense areas in the brain white matter.

\section{DISCUSSION}

To the best of our knowledge this study is the first series of childhood optic neuritis published in the Brazilian literature. We have used a restrictive set of criteria for the diagnosis of optic neuritis in this series. We did not include, therefore, patients in whom papillitis was associated with macular edema and retinal exudates as this condition, commonly denominated neuroretinitis, has a variety of etiologies, a different pathogenesis other than demyelination, and is not associated with the development of MS. We have also discarded cases with any clinical or laboratory evidence of any neurologic infectious disease or autoimmune condition which could be directly related to the development of the optic neuritis. Finally, in order to analyze the outcome of isolated optic neuritis, patients with previous diagnosis of MS or with neuromyelitis optica were also discarded.

This series confirms that isolated optic neuritis in children has some peculiar findings which may distinguish it from the more commonly seen adult-onset condition, although our data differ in some aspects from those reported in most series in the literature ${ }^{1-5}$. To start with optic neuritis was slightly more common in boys than in girls in the present series, whereas in all other studies there was predominance of females ${ }^{1-6}$. This difference remains to be explained.

The mean age at onset of the disease was 10.9 years in our study, 9.3 years in the series of Leernsnyder et al.' $\mathrm{s}^{4}, 8.6$ years in the Kriss et al. series ${ }^{5}$ and 11 years in the series reported by Lucchinetti et al. ${ }^{6}$.

Attacks of optic neuritis in children are common after a febrile illness. A positive history of a febrile condition, usually an upper respiratory infection can be elicited in more than one third of the patients (37\% in our series; $46 \%$ in Kriss et al.'s series ${ }^{5}$ and $36 \%$ in the cohort reported by Lucchinetti et al. ${ }^{6}$ ). The lower association with a febrile illness in our series and in that reported by Lucchinetti et al. may be the result of the more restrictive diagnostic criteria used in our study but it is still higher than the 
Table 3. Evolution of visual acuity in childhood optic neuritis.

\begin{tabular}{lcccccccc}
\hline Visual acuity & \multicolumn{3}{c}{ Group 1 } & \multicolumn{5}{c}{ Group 2 } \\
\hline & Onset $(\mathrm{n}=24)$ & $\mathrm{FU}(\mathrm{n}=16)$ & Onset $(\mathrm{n}=13)$ & $\mathrm{FU}(\mathrm{n}=7)$ \\
\hline & $\mathrm{n}$ & $\%$ & $\mathrm{n}$ & $\%$ & $\mathrm{n}$ & $\%$ & $\mathrm{n}$ & $\%$ \\
\hline $20 / 20$ & 1 & 4.2 & 8 & 50 & - & - & - & - \\
$20 / 25-20 / 30$ & 3 & 12.6 & 3 & 19 & 1 & 7.7 & - & - \\
$20 / 40-20 / 50$ & 2 & 8.3 & 3 & 19 & 1 & 7.7 & 1 & 14 \\
$20 / 60-20 / 100$ & 1 & 4.2 & - & - & 2 & 15.4 & 4 & 57 \\
$20 / 200$ & 6 & 25 & 1 & 6 & 5 & 38.5 & 2 & 29 \\
$20 / 400$ & 1 & 4.2 & - & - & 1 & 7.7 & - & - \\
$20 / 800$ & - & - & 1 & 6 & 2 & 14.4 & - & - \\
CF & 7 & 29.2 & - & - & 1 & 7.7 & - & - \\
HM & 1 & 4.2 & - & - & - & - & - & - \\
NLP & 2 & 8.3 & - & - & - & - & - & - \\
\hline
\end{tabular}

n: number; FU: follow-up

frequency of a preceding viral syndrome found in adult optic neuritis ${ }^{13}$.

A history of pain associated with the visual loss was found in only 10 of our patients (37\%). Lucchinetti et al. ${ }^{6}$ observed the same frequency in their cohort and it dramatically contrasts with the $92 \%$ frequency of pain found in adult optic neuritis ${ }^{13}$. This striking difference may be due to the difficulty in getting information from children. This issue had not been addressed by other authors.

The high frequency of bilateral simultaneous involvement is another differential characteristics of childhood optic neuritis. Bilateral optic neuritis in adults is very rare ${ }^{14}$. Ten children (37\%) in the present study had bilateral optic neuritis (eight bilateral simultaneous and two bilateral sequential). The frequency of bilateral involvement in our cohort is lower than those reported by other authors. Bilateral simultaneous optic neuritis was reported by Leernsnyder et al. ${ }^{4}$ in $71 \%$, by Kriss et $\mathrm{al}^{5}$ in $64 \%$, and by Lucchinetti et al. ${ }^{6}$ in $42 \%$ of their cases. The higher frequency of bilateral simultaneous optic neuritis in some studies may suggest a stronger implication of an infection agent in those series.

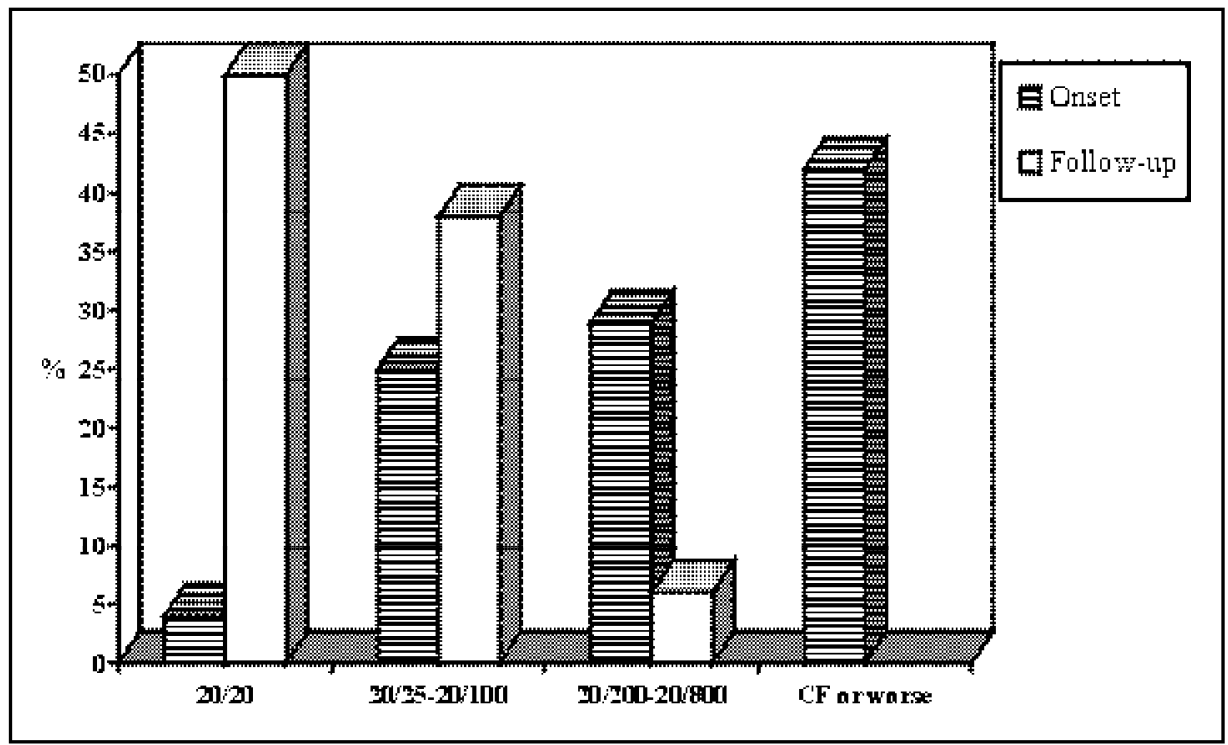

Fig 1. Evolution of visual acuity in Group 1 patients. 


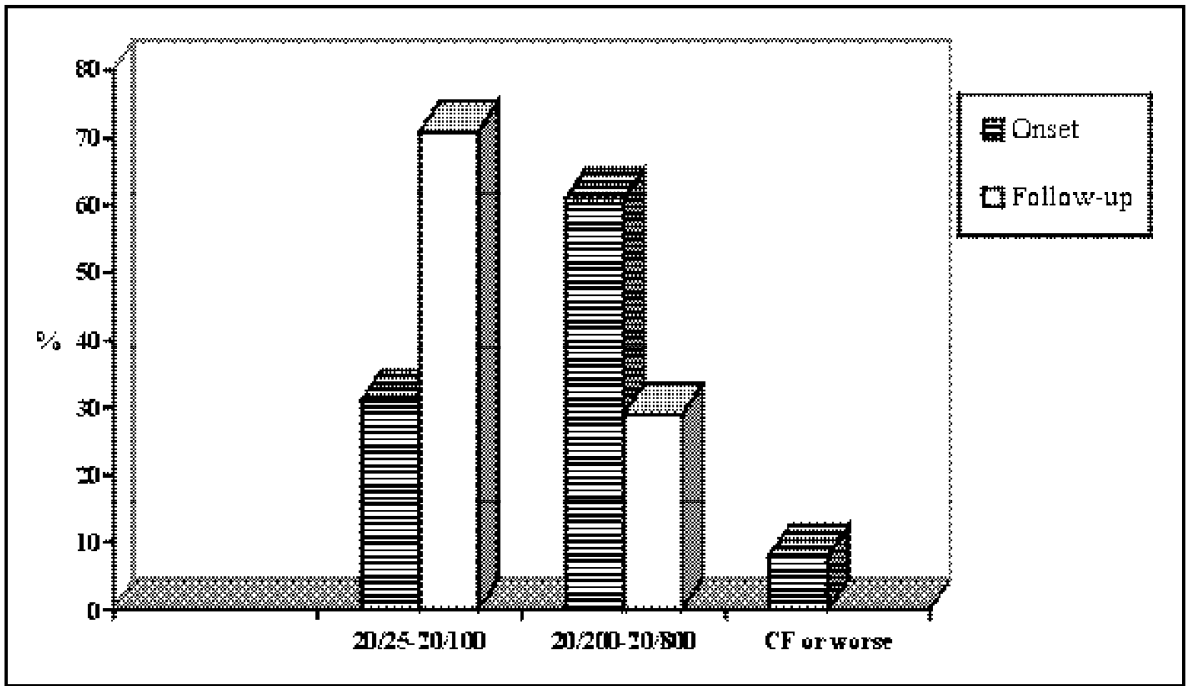

Fig 2. Evolution of visual acuity in Group 2 patients.
In order to assess the visual outcome of optic neuritis in children we divided our cases into two groups according to the interval between the onset of the visual loss and the time they were first examined by us. In children seen in the acute phase of their visual loss (Group 1), VA was more severely affected than in those evaluated after development of optic atrophy (Group 2), suggesting that there had been some degree of recovery in the latter group. A striking recovery of the VA was observed in group 1 patients. Marked recovery of vision following childhood optic neuritis had already been observed by other authors ${ }^{1-6}$, suggesting that children's optic nerve has a high capacity for remyelination. Still more important is our observation that there was visual recovery in almost all patients whose optic discs were already pale at the time we first examined them. In some of these patients optic neuritis might have occurred months or even years earlier. The same finding was reported by Lucchinetti et al. ${ }^{6}$. These findings favor the hypothesis that children retain a capability for remyelination of their optic nerves for a long time.

Optic disc edema is found more commonly in children than in adults with optic neuritis. We found swollen discs in $46 \%$ of our cohort, whereas Kennedy and Carrol reported $70 \%$, Leersnyder et al. ${ }^{4} 85 \%$, Kriss et al. ${ }^{5} 74 \%$ and Lucchinetti et al. ${ }^{6} 47 \%$. The lower percentage of children with optic disc edema in ours and in the cases reported by Lucchinetti et al. ${ }^{6}$, as compared with frequencies observed by other investigators, may be due to inclusion in both of our series of patients with optic disc atrophy. If these cases had been excluded in our series the frequency of optic disc edema would rise to $71 \%$, a figure simi- lar to those found by most authors. By contrast, optic disc edema has been observed in only $35 \%$ of cases of adult-onset optic neuritis ${ }^{13}$.

Visual field testing in our series demonstrated a dense central or cecocentral scotoma in $50 \%$, whereas there was some impairment of color vision in all children. Kriss et $\mathrm{al}^{5}$ found central scotoma and color vision deficits in $98 \%$ of their cases.

CSF examination in childhood optic neuritis may show slight pleocytosis and elevated protein content, but more frequently is normal ${ }^{2,4,5}$. In our patients CSF examination was unrevealing except for increased content of $\gamma$-globulin, suggesting an inflammatory reaction in the CNS. As there is no marker for the diagnosis of demyelinating optic neuritis a major importance of CSF examination is to rule out other neurological disorders which may cause visual disturbances and optic disc changes simulating idiopathic optic neuritis.

Cranial MRI using advanced techniques demonstrates signal abnormalities in $84 \%$ of the symptomatic and $20 \%$ of the asymptomatic optic nerve with optic neuritis ${ }^{15}$. Abnormalities in the cerebral white matter in these patients can be detected in 56 to $72 \%$ of cases $^{16}$.

Conversion to MS is a dreadful perspective in patients with isolated demyelinating optic neuritis. In adult-onset optic neuritis the rate of conversion varies in different geographical regions reaching rates in New England area as high as $74 \%$ of women and $34 \%$ of men within 10 years after the initial attack 9 . In Brazil we found a $10.7 \%$ rate after a mean of 4.8 years of follow-up, a figure similar to those described in Japan and other Eastern countries, demonstrat- 
ing that environmental and genetic aspects play a role not only in the clinical expression of the disease, but also in the rate of its development from isolated idiopathic optic neuritis ${ }^{10}$. In the present series just one child (4\%) developed MS during follow-up, a rate lower than one-half the one we found in our previous adult series ${ }^{10}$. The conversion rate we observed in children is close to that reported by Parkin et $\mathrm{al}^{7}$ who found that only one of his 19 patients developed further evidence of MS after a mean follow- up of 26 years. Kriss et al ${ }^{5}$ found a conversion rate of $15 \%(6 / 33)$ in their series, whereas Kennedy and Carter ${ }^{1}$ reported an overall frequency of MS of $16.5 \%(3 / 18)$.

Lucchinetti et al. ${ }^{6}$ studied the risk factors for developing MS in a cohort of 79 children with optic neuritis during a mean follow-up of 19.4 years. Life table analysis showed that $10 \%$ of the children progressed to MS by 10 years of follow-up, $19 \%$ by 20 years and $26 \%$ by 40 years. Bilateral sequential or recurrent optic neuritis increased the risk of developing MS; gender, age, fundoscopic findings, visual acuity or family history did not predict the development of multiple sclerosis, whereas presence of infection within two weeks before the onset of optic neuritis decreased the risk. Our findings are in agreement with these observations confirming that optic neuritis in children is a more benign condition and has a lower rate conversion to MS.

Our study also demonstrates a number of clinical peculiarities of optic neuritis in children distinguishing it from that seen in adults. Aside from the predominance of boys and a still lower conversion rate to multiple sclerosis in our cohort, we were unable to find other particular distinguishing features of optic neuritis in Brazilian children as compared with other series in the literature.
Although the clinical picture of childhood optic neuritis can be well delineated the nature of the inflammatory process in children's optic nerve, as well as the reasons for its better visual and neurological outcome remain unknown. It is possible that idiopathic optic neuritis in children is a different process than that occurring in adults. Further studies are necessary to clarify these issues.

\section{REFERENCES}

1. Kennedy C, Carter S. Relation of optic neuritis to multiple sclerosis in children. Pediatrics 1961;28:377-387.

2. Taylor D, Cuendet F. Optic neuritis in childhood. In Hess RF, Plant GT (eds).. Optic Neuritis. Cambridge: Cambridge Press, 1986;73-85.

3. Meadows SP. The Downe Memorial Lecture: Retrobulbar and optic neuritis in childhood and adolescence. Trans Ophthalmol Soc UK 1969;89:603-638.

4. Leersnyder H, Bursztyn J, Ponsot G et al. Névrites optiques de l'énfant. Aspects cliniques et évolutifs. A propos de 14 observations. Arch Fr Pediatr 1981;38:563-568.

5. Kriss A, Francis DA, Cuendet F et al. Recovery after optic neuritis in chidhood. J Neurol Neurosurg Psychiatry 1988;51:1253-1258.

6. Lucchinetti CF, Kiers L, O'Duffy A, et al. Risk factors for developing multiple sclerosis after childhood optic neuritis. Neurology 1997;49:413-418.

7. Parkin PJ, Hierons R, McDonald WI. Bilateral optic neuritis. A long term follow-up. Brain 1985;197:951-964.

8. McDonald WI. Doyne Lecture: The significance of optic neuritis. Trans Ophthalmol Soc UK 1983;103:230-246.

9. Rizzo JF, Lessell S. Risk of developing multiple sclerosis after uncomplicated optic neuritis. Neurology 1988; 38:185-190.

10. Lana-Peixoto MA, Lana-Peixoto MI. The risk of multiple sclerosis developing in patients with isolated idiopathic optic neuritis in Brazil. Arq Neuropsiquiatr 1991;49:377-383.

11. Lana-Peixoto MA, Lana-Peixoto MI. Is multiple sclerosis in Brazil and Asia alike? Arq Neuropsiquiatr 1992;50:419-425.

12. Poser CM, Paty DW, Scheinberg L et al. New diagnostic criteria for multiple sclerosis: guidelines for research protocols. Ann Neurol 1983;13:227-231.

13. Optic Neuritis Study Group. The clinical profile of optic neuritis: optic neuritis treatment trial. Arch Ophthalmol 1991;109:1673-1678.

14. Perkin GD, Rose CF. Optic Neuritis and its differential diagnosis. Oxford: Oxford University Press, 1979; 217-220.

15. Miller DH, Newton MR, van der Poel JC et al. Magnetic resonance imaging of the optic nerve in optic neuritis. Neurology 1988, 38:175179.

16. Scholl GB, Song HS, Wray SH. Uhthoff symptom in optic neuritis: Relationship to magnetic resonance imaging and development of multiple sclerosis. Ann Neurol 1991;30:180-184. 